\title{
Enterococcus gallinarum MENINGITIS IN AN IMMUNOCOMPETENT HOST: A CASE REPORT
}

\author{
Vicente Sperb ANTONELLO(1), Francis de Moura ZENKNER(2), Josiane FRANÇA(3) \& Breno Riegel SANTOS(1)
}

\begin{abstract}
SUMMMARY
We describe a rare case of a 53-year-old man with a long history of alcohol abuse, with Enterococcus gallinarum meningitis, an organism that rarely causes human infection and is primarily found in the gastrointestinal tract of poultry. The patient improved with high-dose ampicillin and gentamicin therapy. To our knowledge, this is the first Brazilian reported case of E. gallinarum meningitis and probably the first case described in an immunocompetent host.
\end{abstract}

KEYWORDS: Enterococcus; Enterococcus gallinarum; Meningitis; Alcohol abuse.

\section{INTRODUCTION}

Enterococci are gram-positive, facultative anaerobic cocci that are ovoid in shape and are difficult to distinguish from streptococci on Gram $\operatorname{stain}^{6,8}$. They are usually associated with urinary tract and cardiovascular infections, while enterococcal involvement in central nervous system (CNS) rarely occurs in immunocompetent adults ${ }^{5,9,10}$. E. faecalis and E. faecium are the two most commonly encountered enterococcal species, together accounting for $90 \%$ of isolates ${ }^{6,8}$. Other species, including $E$. gallinarum are uncommonly encountered in human clinical specimens and are primarily found in the gastrointestinal tracts in poultry ${ }^{3,8}$. Infection by E. gallinarum rarely occurs and has been implicated in a few invasive infections in humans, especially in immunocompromised or chronically ill patients ${ }^{2,3,5}$. There are only four cases of CNS involvement reported in literature due to this unusual germ, all reporting on patients with some degree of immunosuppression who had been previously submitted to a neurological procedure ${ }^{4,8,9,10}$. In this paper we describe one case of meningitis caused by E. gallinarum in an immunocompetent host.

\section{CASE REPORT}

A 53-year old man was admitted to a public general hospital with a history of weakness, malaise, weight loss, mental confusion, fever and ataxia for 15 days prior to hospitalization. He had a background history of partial gastrectomy and cholecystectomy, 20 and 10 years before, respectively. He also had history of heavy alcohol intake for many years. On physical examination the patient presented fever (axillary temperature of $38.5^{\circ} \mathrm{C}$ ), nuchal rigidity and mental confusion. A computed tomography (CT) scan of the brain showed dilatation of the ventricular system, with reduction of cerebellum volume. Lumbar puncture was performed, with cerebrospinal fluid (CSF) opening pressure of $100 \mathrm{mmH} 2 \mathrm{O}, 240$ cells $/ \mathrm{mm}^{3}$, with neutrophil predominance, glucose of $21 \mathrm{mg} / \mathrm{dL}$ and protein of $270 \mathrm{mg} / \mathrm{dL}$. Laboratory findings were as follows: serum creatinine $0.31 \mathrm{mg} / \mathrm{dL}$; potassium $3.4 \mathrm{mEq} / \mathrm{L}$; sodium $111 \mathrm{mEq} / \mathrm{L}$; RBC $345 \times 10^{4} / \mathrm{L}$; WBC 1,16 X 104/L with a left shift. Intravenous ceftriaxone was started. There was no significant improvement of general status in the first 24 hours. At this time, patient developed respiratory distress and was admitted to the ICU requiring mechanical ventilation. Using the automated system Vitek $2^{\circledast}$, result from CSF culture grew Enterococcus gallinarum, sensitive, as shown by MIC, to almost all tested antibiotics, including ampicillin, penicillin, aminoglycosides, macrolides, tetracyclines, quinolones and only resistant to vancomycin. Blood and urine cultures, echocardiography, ultrasound and CT scan were unremarkable.

Ampicillin $12 \mathrm{~g} /$ day with gentamicin ( $7 \mathrm{mg} / \mathrm{kg}$ per day) was substituted for ceftriaxone and continued for three weeks. On the third day of treatment, another lumbar puncture was carried out, this time with negative culture. The patient gradually recovered mental status and was discharged with improved verbal, motor and ocular functions.

\section{DISCUSSION}

Enterococci uncommonly cause meningitis in normal adults. Most cases of enterococcal meningitis occur in patients with anatomic defects of CNS, prior neurosurgery, head trauma or immunosuppression ${ }^{1,4,5,7}$. Two presentations of enterococcal meningitis are usually described: postoperative and spontaneous. Meningitis is a rare complication of highgrade bacteremia in patients with enterococcal endocarditis, especially in patients with AIDS and acute leukemias 5 .

Enterococcus gallinarum, first described by Bridge \& Sneath in 1982 as a streptococcus, and later redefined as anenterococcus by Collins in 1984, is a rare enterococcal species; more commonly found 
ANTONELLO, V.S.; ZENKNER, F.M.; FRANÇA, J. \& SANTOS, B.R. - Enterococcus gallinarum meningitis in an immunocompetent host: a case report. Rev. Inst. Med. Trop. Sao Paulo, 52(2):111-2, 2010.

Table 1

Central nervous system infection by Enterococcus gallinarum reported in the literature

\begin{tabular}{lllll}
\hline Reference & Age, Sex & Clinical presentation & Potential predisposing & Treatment \\
\hline 7 & $64 \mathrm{yr}, \mathrm{M}$ & Fever and lethargy & VP shunt & i.v. Ampicillin \& Gentamicin for 3 weeks \\
1 & $51 \mathrm{yr}, \mathrm{F}$ & Fever and headache & Previous lumbar drainage of CSF & i.v. Rifampin \& Ampicillin for 3 weeks \\
3 & $57 \mathrm{yr}, \mathrm{M}$ & Fever and neck stiffness & VP shunt and RA & i.v. Teicoplamin for 4 weeks \\
3 & $12 \mathrm{yr}, \mathrm{M}$ & Fever and drowsiness & VP shunt and astrocytoma & i.v. Ampicillin for 8 weeks \\
Present report & $53 \mathrm{yr}, \mathrm{M}$ & Fever, neck stiffness \& & Alcohol abuse & i.v. Ampicillin \& Gentamicin for 3 weeks \\
\hline
\end{tabular}

M, male; F, female; CSF, cerebrospinal fluid; RA, Rheumatoid arthritis; VP, Ventriculoperitoneal.

in gastrointestinal tract of certain animals, and can sporadically cause infection ${ }^{6}$. In a review of the literature, only four cases of meningitis by E. gallinarum were found as shown in Table 1 . In all cases, a neurological procedure was performed prior to diagnosis (three with ventriculoperitoneal shunt and one with a lumbar drain $)^{4,8,9,10}$. We describe here a case of E. gallinarum meningitis in a 53-year-old man, with a long history of alcohol abuse. In this case, there was unquestionable evidence of CNS infection, as demonstrated by mental confusion, fever, neck stiffness and neutrophillic pleocytosis on cerebrospinal fluid, with markedly high protein and low glucose. The infection of the CNS may have been associated with E. gallinarum derived from the gut, given that there was no other evidence of enterococcal infection or underlying diseases. The patient presented severe hyponatremia, which can be explained by the Syndrome of Inappropriate Secretion of Antidiuretic Hormone, secondary to the CNS infection.

The option for ampicillin and aminoglycoside was based on two important facts: the antibiogram and synergy of both antimicrobials, as recommended for CNS infections due to Enterococci, although there is no consensus about the best choice between monotherapy or combination therapy $y^{4,7}$. The occurrence of vancomycin resistance in our case was expected, regarding a natural characteristic of motile species of enterococci in expressing Glycopeptide resistant genes. The duration of treatment was based on previous reports of treatment of enterococcal meningitis $\mathrm{s}^{4,5,7,8,10}$.

To our knowledge, this is the first Brazilian reported case of Enterococcus gallinarum meningitis. In conclusion, a proper bacteriological diagnosis is of paramount importance for the guidance of therapy due to the possibility of an uncommon etiology as in this case. Unique to this case also, was the occurrence of E. gallinarum meningitis in a host without immunodeficiency other than alcohol abuse.

\section{RESUMO}

\section{Meningite por Enterococcus gallinarum em paciente sem imunodepressão: relato de caso}

Descrevemos caso raro de paciente de 53 anos com história de alcoolismo prévio, com meningite por Enterococcus gallinarum, um organismo que raramente causa infecções em humanos e é encontrado principalmente no trato gastrointestinal de aves. $\mathrm{O}$ paciente teve melhora importante após início de tratamento intravenoso com ampicilina e gentamicina combinados. Para o nosso conhecimento, este é o primeiro caso relatado de meningite por E. gallinarum no Brasil e possivelmente o primeiro caso descrito em paciente sem imunodepressão.

Conflict of Interest: None to declare.

Funding: None to declare.

Ethical Approval: Subjects gave informed consent to the work.

\section{REFERENCES}

1. Bayer AS, Seidel JS, Yoshikawa TT, Anthony BF, Guze LB. Group D enterococcal meningitis. Clinical and therapeutic considerations with report of three cases and review of the literature. Arch Intern Med. 1976;136:883-6.

2. Corso A, Faccone D, Gagetti P, Togneri A, Lopardo H, Melano R, et al. First report of VanA Enterococcus gallinarum dissemination within an intensive care unit in Argentina. Int J Antimicrob Agents. 2005;25:51-6.

3. Dargere S, Vergnaud M, Verdon R, Saloux E, Le Page O, Leclercq R, et al. Enterococcus gallinarum endocarditis occurring on native heart valves. J Clin Microbiol. 2002;40:2308-10.

4. Kurup A, Tee WS, Loo LH, Lin R. Infection of central nervous system by motile Enterococcus: first case report. J Clin Microbiol. 2001;39:820-2.

5. Murray BE, Arias CA. Enterococcus species, Streptococcus bovis group, and Leuconostoc species. In: Mandell GL, Bennett JE, Dolin R. Mandell, Douglas and Bennett's principles and practice of infectious diseases. $7^{\text {th }}$ ed. New York: Churchill Livingstone; 2009. p. 2643-53.

6. Murray BE. The life and times of the Enterococcus. Clin Microbiol Rev. 1990;3:4665.

7. Pintado V, Cabellos C, Moreno S, Meseguer MA, Ayats J, Viladrich PF. Enterococcal meningitis: a clinical study of 39 cases and review of the literature. Medicine (Baltimore). 2003; 82:346-64

8. Roca B, Pesudo JV, Gonzalez-Darder JM. Meningitis caused by Enterococcus gallinarum after lumbar drainage of cerebrospinal fluid. Eur J Intern Med. 2006;17:298-9.

9. Sato K, Oka H, Utsuki S, Shimizu S, Suzuki S, Yamada M, et al.. [Vancomycinresistant Enterococcal meningitis in patients with ventriculoperitoneal shunt: two cases report and review of the literature]. No Shinkei Geka. 2006;34:203-7.

10. Takayama Y, Sunakawa K, Akahoshi T. Meningitis caused by Enterococcus gallinarum in patients with ventriculoperitoneal shunts. J Infect Chemother. 2003; 9:348-50.

Received: 16 December 2009

Accepted: 18 February 2010 